\title{
Ґендерна рівність
}

\section{Наталя Костюк, Олена Антонюк, Дніпровський національний університет залізничного транспорту ім. академіка В. Лазаряна}

Стаття присвячена дослідженню гендерної рівності в економічній, політичній та соціальній сферах України та визначенню основних причин, проявів сучасного гендерного дисбалансу щодо дотримання та реалізації прав, можливостей жінок. Актуальність цієї статті полягає в необхідності системного вирішення проблеми гендерного рівноправ'я в Україні між жінками та чоловіками, що закріплено на конституційному рівні, як найголовніший принцип забезпечення законодавчих прав і свобод людини в демократичній державі.

У дослідженні проведено аналіз чинної нормативно-правової бази України, а також низки ратифікованих міжнародних договорів у сфері забезпечення гендерної рівності. На основі даних Всесвітнього економічного форуму, зокрема, аналізу індексу гендерного розриву за окремими сферами діяльності та гендерного моніторингу представництва кандидатів на позачергових виборах народних депутатів України у 2014 та 2019 рр., виявлено сучасний стан реалізації основних напрямів соціальної політики України в сфері гендерної рівності. Окремо звернуто увагу на вплив гендерної дискримінації жінок на соціально-економічний розвиток країн світу та рівень їх національного багатства.

За результатами дослідження відзначено позитивну тенденцію реалізації права участі та представництва жінок в економічному, та політичному напрямках діяльності України, а також запропоновані подальші необхідні заходи держави в соціальній політиці щодо усунення гендерної асиметрії в українському суспільстві. Наголошено на тому, що в умовах загострення економічних, політичних та соціальних потрясінь в Україні, проблема гендерної сегрегації, множинної дискримінації жінок, потребує переорієнтації гендерної політики держави на більш ефективні заходи подолання гендерної нерівності. У підсумку зроблено висновок про те, що розвиток політичної та правової концепції викорінення гендерної дискримінації жінок в Україні є головною запорукою сталого розвитку українського суспільства, що, у свою чергу, є необхідною умовою для формування конкурентоспроможного людського капіталу країни 3 євроінтеграційним зовнішньополітичним курсом.

Ключові слова: тендерна дискримінація, тендерне представнищтво, тендерна рівність, тендерні стереотипи, сексизм, соціальна політика, фемінізм

\section{Gender inequality}

\section{Natalia Kostiuk, Olena Antoniuk, Dnipro National University of Railway Transport named after Academician V. Lazaryan}

The article deals with gender inequality in the economic, political and social spheres of Ukraine and the key reasons for gender imbalance in the observation and realization of gender rights. The topicality of the article is predetermined by the necessity of the systemic solution to the problem of gender equality in Ukraine that is declared in the country's constitution as the pivotal principle of safeguarding legal rights and freedoms of people in a democratic state.

The authors have made an analysis of the Ukrainian norms and laws in force as well as some ratified international treaties in the sphere of gender equality insurance. The current state of realization of the main directions of social policy of Ukraine in the sphere of gender equality has been determined on the basis of the World Economic Forum and in particular the analysis of the index of gender discrepancy in certain spheres of human activity as well as the gender monitoring of the representation of candidates in the special election of people's deputies of Ukraine in 2014 and 2019. The impact of gender discrimination against women on the social economic development of the world countries and their national wealth level has been considered. 
The study has allowed revealing a positive tendency in the realization of women's right to participate and be represented in the economic and political spheres of Ukrainian activity and offering further necessary state measures in the social policy pertaining to the eradication of gender asymmetry in the Ukrainian society. The need of redirecting the government gender policy to more effective measures for overcoming gender inequality, gender segregation and multiple forms of discrimination against women under the conditions of the severe economic, political and social upheavals in Ukraine has been pointed to. The authors have come to the conclusion that the development of the political and juridical concept of eradication of gender discrimination against women in Ukraine is the pledge of sustainable development of the Ukrainian society which in its turn is a necessary condition for forming a competitive human capital of the country that has chosen the Eurointergation foreign policy course.

Keywords: gender discrimination, gender representedness, gender equality, gender stereotypes, sexism, social policy, feminism

\section{Гендерное равенство}

\section{Наталья Костюк, Елена Антонюк, Днепровский национальный университет железнодорожного транспорта им. академика В. Лазаряна}

Статья посвящена исследованию гендерного равенства в экономической, политической и социальной сферах Украины и определению основных причин, проявлений современного гендерного дисбаланса относительно соблюдения и реализации прав, возможностей женщин. Актуальность этой статьи заключается в необходимости системного решения проблемы гендерного равноправия в Украине между женщинами и мужчинами, что закреплено на конституционном уровне, как самый главный принцип обеспечения законодательных прав и свобод человека в демократическом государстве.

В исследовании проведен анализ действующей нормативно-правовой базы Украины, а также ряда ратифицированных международных договоров в сфере обеспечения гендерного равенства. На основе данных Всемирного экономического форума, в частности, анализа индекса гендерного разрыва по отдельным сферам деятельности и гендерного мониторинга представительства кандидатов на внеочередных выборах народных депутатов Украины в 2014 и 2019 гг., выявлено современное состояние реализации основных направлений социальной политики Украины в сфере гендерного равенства. Отдельно обращено внимание на влияние гендерной дискриминации женщин на социально-экономическое развитие стран мира и уровень их национального богатства.

По результатам исследования отмечена позитивная тенденция реализации права участия и представительства женщин в экономическом и политическом направлениях деятельности Украины, а также предложены дальнейшие необходимые меры государства в социальной политике относительно устранения гендерной асимметрии в украинском обществе. Отмечено то, что в условиях обострения экономических, политических и социальных потрясений в Украине, проблема гендерной сегрегации, множественной дискриминации женщин, нуждается в переориентации гендерной политики государства на более эффективные мероприятия преодоления гендерного неравенства. В итоге сделан вывод о том, что развитие политической и правовой концепции искоренения гендерной дискриминации женщин в Украине является главным залогом устойчивого развития украинского общества, которое, в свою очередь, является необходимым условием для формирования конкурентоспособного человеческого капитала страны с евроинтеграционным внешнеполитическим курсом.

Ключевые слова: гендерная дискриминация, гендерное представительство, гендерное равенство, гендерные стереотипы, сексизм, сочиальная политика, феминизм 


\section{Постановка проблеми.}

$\Pi$ роблема формування принципово нових, звільнених від усталених стереотипів гендерних стосунків в суспільстві України займає одне з провідних місць у дослідженнях сучасних соціальних наук. Актуальність науково обгрунтованого вирішення ґендерної нерівності між чоловіками та жінками в українському суспільстві полягає в іiі повному викоріненні, а також в забезпеченні дійсного рівноправ'я між ними як необхідної умови ефективного розвитку людського капіталу в країні.

Попри те, що з часу проголошення незалежності України була сформована національна нормативно-правова база та імплементована міжнародна, що регулює питання гендерної рівності та розширення повноважень жінок, країна досі стикається 3 викликами, які виявляються в множинній дискримінації жінок, їх гендерно зумовленому насильстві, обмеженій участі в ухваленні рішень в економічній, політичній та соціальній сферах тощо. Поширена дискримінація жінок багато в чому зумовлена патріархальними стереотипами та уявленнями, а також слабким верховенством права, низькою спроможністю до впровадження інституційних механізмів щодо забезпечення гендерної рівності. До того ж, розвиток ринкових відносин, загострення військового конфлікту на Сході України, а також соціальної, економічної та політичної кризи, поглибили ще більше наявну гендерну нерівність та сформували нові виклики для захисту та реалізації прав жінок в Україні (Гендерна рівність). 3 огляду на нові виклики в системі гендерного рівноправ'я жінок та чоловіків в Україні та на активізацію зовнішньополітичного курсу держави на європейську та євроатлантичну інтеграцію, постає необхідність продовження наукового пошуку шляхів подолання гендерного дисбалансу та розширення гендерної рівності жінок відповідно до сучасного розвитку соціально-економічної системи на національному та світовому рівнях.
Аналіз останніх досліджень і публікацій.

Динамічний розвиток гендерного дисбалансу між чоловіками та жінками в Україні, а також постійне порушення законодавчо визначених прав жінок та можливостей щодо їх реалізації спонукають до систематичного наукового вивчення проблеми гендерної дискримінації в Україні. Вона належить до площини наукових інтересів багатьох вітчизняних науковців, які зосередили увагу на дослідженні гендерної асиметрії, зокрема, у сфері функціонування політичних інститутів, трансформації політичної системи в умовах реалізації рівних прав, можливостей жінок та чоловіків тощо. Ці дослідження знаходять своє відображення в наукових працях В. І. Архіпова, В. М. Черби, Г. Я. Дідух, Л. А. Літвін, Т. М. Мельник, Т. О. Марценюк, Н. А. Гербут та ін.

При цьому поява та розвиток феміністської політичної думки в Україні зумовлена становленням феміністської або гендерної теорії американських вчених С. Дж. Керролл і Л. М. Зеріллі ще на початку XXI ст., а також низкою узагальнених жіночих і гендерних наукових досліджень у сфері політичної теорії А. М. Янг. Проте, незважаючи на досить велику кількість наукових досліджень проблеми гендерної рівності в Україні, постійна зміна векторів діяльності політичної, економічної та соціальної сфери держави, а також поглиблення міжнародної співпраці країн щодо подолання ґендерного розриву в світовому суспільстві вимагає продовження наукового аналізу гендерно зумовленої дискримінації.

Метою статті $\epsilon$ аналіз сучасного стану проблеми гендерної рівності в Україні, 3'ясування основних причин та форм поширення гендерного дисбалансу в соціально-економічних відносинах українського суспільства та визначення основних стратегічних інституційних механізмів держави щодо забезпечення повноцінного гендерного рівноправ'я в довгостроковій перспективі. 


\section{Виклад основного матеріалу.}

Принцип гендерної рівності жінок в Україні законодавчо закріплений у Конституції України - статтями 3, 21, 23 та 24, яка безпосередньо присвячена подоланню дискримінації стосовно жінок в Україні та закріплює рівність чоловіків та жінок в усіх сферах життя (Про забезпечення рівних прав та можливостей жінок і чоловіків, 2005). Законодавча база України щодо гендерної рівності включає також «Угоду про асоціацію між Україною, з однієї сторони, та Європейським Союзом, Європейським співтовариством 3 атомної енергії і їхніми державами-членами, з іншої сторони» (2014 p.), яка гарантує рівні можливості для жінок та чоловіків у сферах працевлаштування, освіти, навчання, економіки, у суспільстві. Крім цього, у 2015 р. було прийнято Національну доповідь «Цілі Сталого Розвитку: Україна», Стратегію та План дій з реалізації Національної стратегії у сфері прав людини, метою яких $\epsilon$ гарантування рівних прав та можливостей для жінок та чоловіків в усіх сферах життя. А «Нова Державна соціальна програма забезпечення рівних прав та можливостей жінок і чоловіків на період до 2021 року» (2018 р.) спрямована на укріплення інституційних механізмів забезпечення гендерної рівності з комплексним підходом до подолання інституційних обмежень.

Також Україна керується великою кількістю підписаних та ратифікованих міжнародних документів у сфері забезпечення гендерної рівності та запобігання насильству жінок. Одним з основних та найперших фундаментальних документів, який включив питання рівності чоловіків та жінок, став Статут Організації Об'єднаних Націй (далі ООН). Його було прийнято 192-ма країнами світу у 1945 р., які зобов'язалися дотримуватися принципу рівності прав чоловіків та жінок, захисту просування прав жінок. У 1995 р. країна приєдналася до Пекінської Декларації та Платформи Дій на IV-й Міжнародній конференції із становища жінок, ратифікува28 ла ключові договори 3 прав людини, включно з Конвенцією ООН «Про ліквідацію всіх форм дискримінації щодо жінок» (1979 р.) та іiі Факультативного Протоколу (1999р.) (Гендерна рівність). Окремо слід звернути увагу на Конвенції Міжнародної організації праці (далі - МОП), ратифіковані Україною. Адже саме МОП визначає міжнародні трудові норми, які грунтуються на визнанні прав працюючих жінок, як невід'ємної складової цінностей, принципів і завдань, що визначають сутність мандату МОП, спрямованого на заохочення соціальної справедливості, гідної праці та сталого розвитку (Азбука прав працюючих жінок і гендерної рівності, 2010, c. 4). Україна ратифікувала наступні Конвенції МОП у сфері праці, які стосуються запровадження ґендерної рівності у сфері праці та розширення економічних можливостей жінок:

- Конвенція Міжнародної організації праці «Про рівне винагородження чоловіків і жінок за працю рівної цінності № 100», підписана Україною 29.06.1951р.;

- Конвенція «Про охорону материнства» (переглянута в 1952 році) № 103 (28.06.1952 р.);

- Конвенція Міжнародної організації праці «Про дискримінацію в галузі праці та занять № 111» (25.06.1958 р.);

- Конвенція Міжнародної організації праці № 156 «Про рівне ставлення й рівні можливості для трудящих чоловіків і жінок: трудящі із сімейними обов'язками» (23.06.1981 p.).

Важливим кроком у напрямку захисту прав жінок в умовах збройного конфлікту та забезпечення їх активної участі у миротворчих процесах в Україні стало ухвалення Урядом Національного плану дій 3 виконання резолюції Ради Безпеки ООН 1325 «Жінки, мир, безпека» (2016 р.). Окрім цього, у 2017 p., Україна криміналізувала на законодавчому рівні домашнє насильство 3 метою його попередження, що відповідає положенням Конвенції Ради Свропи «Про запобігання насильству стосовно жінок і домашньому 
насильству та боротьбу 3 цими явищами» (Стамбульська Конвенція) [5].

Підтримка України щодо збільшення політичної, соціальної та економічної участі жінок та зміцнення їхньої ролі у процесі здійснення національних реформ відбувається через діяльність Представництва ООН в Україні. Це сприяє дотриманню державою своїх зобов'язань за міжнародними угодами, а також досягненню Цілей Сталого Розвитку до 2030 р. Окремим інститутом Представництва ООН в Україні щодо вирішення гендерних проблем, який встановлює ефективне партнерство між ООН, Урядом, Парламентом та громадянським суспільством в усіх сферах гендерної рівності та прав жінок в Україні, є Гендерна тематична група ОOH. Вона, як міжвідомчий механізм координації діяльності системи ООН, впроваджує гендерну рівність у країні через надання технічної підтримки, експертизи щодо гендерного інтегрування та координацію питань, пов'язаних з плануванням та адвокацією відповідно до Рамкової Програми Партнерства між Урядом України та ООН на 2018 -2022 рр. (Гендерна рівність). Наприклад, основними напрямами діяльності Гендерної тематичної групи ООН щодо подолання гендерної нерівності в Україні є наступні:

- «Стале економічне зростання, навколишнє середовище і зайнятість»-зменшення гендерного розриву в оплаті праці між чоловіками та жінками, просування для них гідних умов праці та рівний розподіл між ними домашніх обов'язків тощо.

- «Рівний доступ до якісних та інклюзивних послуг і соціального захисту» - подолання епідемії ВІЛ, шкідливих соціальних норм та стереотипів тощо.

- «Демократичне врядування, верховенство права і громадська участь»-зосередження уваги на гендерній рівності під час виконання національних реформ, низькому рівні представленості жінок в економічній та політичній сфері зайнятості, впровадження ґендерних квот тощо.
- «Безпека громадян, соціальна єдність і відновлення з особливим акцентом на Східну Україну» - подолання гендерно-обумовленого насильства та інше.

Незважаючи на досить розвинену нормативно-правову базу України та координацію дій держави з питань гендерної рівності інститутами ООН, у країні поглиблюється проблема системної гендерної нерівності. Наприклад, гендерно зумовлене насильство найбільш поширене серед жінок у формах фізичної, сексуальної, психологічної агресії або контролюючої поведінки: 22 \% жінок віком 15-49 років пережили принаймні одну 3 форм фізичного або сексуального насильства (Цілі сталого розвитку: України: Національна доповідь, 2017, с. 42). До того ж жінки складають 76,5 \% потерпілих від торгівлі людьми. Основним проявом гендерної нерівності жінок в економічних можливостях населення $\epsilon$ незбалансованість у рівні заробітної плати. Гендерний розрив у середньомісячній оплаті праці жінок щодо чоловіків у 2019 р. склав 72,2 \% та досяг більше 90 \% у деяких економічних сферах (Державна служба статистики України). Вагомим чинником гендерної дискримінації жінок в економічній зайнятості є також поширеність укорінених гендерних стереотипів на розподіл сімейних обов'язків. Догляд за членами домогосподарств та ведення хатньої роботи зміщує пріоритети працюючих жінок у бік сімейних обов'язків. Так, частка зайнятих жінок на ринку праці в 2019 р. складає $47,79 \%$, що є нижче на противагу $52,21 \%$ серед чоловіків (Державна служба статистики України). На сьогодні частка чоловіків, які розподіляють сімейні обов'язки щодо виховання дітей, шляхом їх заохочення до використання відпустки по догляду за дитиною до досягнення нею трирічного віку, не перевищує 3 \% (Цілі сталого розвитку: України: Національна доповідь, 2017, с. 42). Окрім цього, сучасні виклики щодо зростання гендерно зумовленого насильства над жінками, браку можливостей для їх гідної за- 
йнятості, пов'язані із розгортанням збройного конфлікту у східних регіонах України та формуванням масштабних потоків внутрішньо переміщених осіб, у складі яких переважають жінки (58 \%, включаючи 74 \% жінок похилого віку). Так, пряма гендерна дискримінація на ринку праці в сфері військової служби виявляється в тому, що частка жінок серед військовослужбовців складає лише 8,5 $\%$, серед офіцерів - 5,3\% та серед солдатів та сержантів - 9,4 \% (Гендерна рівність).

Виходячи з вищенаведеного, можна відзначити, що системна гендерна нерівність в Україна найбільш представлена низьким рівнем участі жінок у спектрі професіонально-трудових напрямків, політичних, економічних та соціальних процесах. Разом з низьким рівнем росту представленості жінок на високих посадах, поширеністю гендерно-обумовленого насильства над ними, це призводить не тільки до падіння їх соціального статусу, але й до унеможливлення сталого соціально-економічного розвитку країни. Це означає, що реформи та нормативно-правові акти, які запроваджує Україна, приділяють не значну увагу питанням гендерної рівності, реалізації захисту прав жінок та виконанню міжнародних, національних зобов’язань у цій сфері.

Рівність чоловіків і жінок у різних країнах світу з низки соціальних, політичних і економічних параметрів щорічно оцінюється рейтингом гендерної рівності Всесвітнього економічного форуму (далі - ВЕФ). Серед критеріїв 3 оцінки гендерної рівності експерти ВЕФ аналізують частку працюючих жінок у загальному працюючому населенні країни, частку жінок серед топ-менеджерів, участь жінок у політиці, доступ до послуг освіти та охорони здоров'я, умови оплати праці. Оцінка гендерного балансу між чоловіками та жінками в різних сферах діяльності оцінюється індексом гендерного розриву (The Global Gender Gap Index), який розраховується за методикою Світового економічного форуму (World Economic Forum) та передбачає аналіз комбінації загально30 доступних статистичних даних у галузі соціально-економічного розвитку 3 різних країн світу. Дослідження охоплює 153 країни у чотирьох основних сферах: освіта, охорона здоров'я та ймовірна тривалість життя, економіка і кар'єра, а також політичні права. У 2020 р. ВЕФ зазначив, що, незважаючи на невелике поліпшення в сфері подолання гендерної нерівності в порівнянні з минулим роком, загалом по світу ситуація залишається дуже далекою від ідеалу. На сьогодні середній ґендерний розрив у світі складає 31,4 $\%$, який ще потребує ліквідації. Поліпшення ситуації з гендерною рівністю в світі за цей рік в основному відбулося в результаті значного зростання кількості жінок у політиці в 108 зі 149 країн, проте тільки 25 \% (у 2018 р. - 24,1 \%) їх працюють у парламентах країн та $21 \%$ (у 2018 р. - $19 \%$ ) жінок займають посади міністрів. Крім цього, за останні 50 років у 85 країнах зі 153-х досліджуваних, жінка ніколи не була главою держави (Global Gender Gap Report, 2020, p. 5).

Значення індексу гендерного розриву показали, що досягнення рівності статей доведеться чекати ще майже століття. Так, якщо поточна тенденція подолання гендерного розриву в політиці, економіці, охороні здоров'я та освіті збережеться, він буде подоланий через 99,5 року та при цьому тільки для 107 країн. Тенденція відображує позитивні зміни в подоланні гендерного дисбалансу, оскільки, ще в 2018 р. значення індексу гендерного розриву в світі становило 108 років. Проте негативним явищем $\epsilon$ те, що цей термін досягнення рівності між чоловіками і жінками перевищує середню тривалість життя людини. При цьому гендерний розрив за економічною участю та можливостями для жінок прогнозується подолати через 257 років (проти 202 років в 2018 р.), за розширенням політичних прав та можливостей 94,5 років (проти 107 років в 2018 р.) та за рівнем освіти - через 12 років (Global Gender Gap Report, 2020, p. 5-6). Зокрема, гендерна нерівність у глобальному економічному на- 
прямку супроводжується стабільним збереженням низького рівня представництва жінок на керівних посадах, повільним зростанням їх заробітної плати, доступності робочих місць і джерел доходу. Наприклад, економічна зайнятість жінок найчастіше виявляється в категоріях середніх і низьких зарплат, які не зростають вже 10 років після глобальної фінансової кризи. Також досить велика частка жінок втратили роботу через автоматизацію трудових процесів (наприклад, роздрібні продажі і офісна робота). Виходячи 3 цього, слід відзначити, що побудова справедливої та інклюзивної світової економіки поставлена під загрозу. Надання рівноцінних прав чоловікам та жінкам у сфері охорони здоров'я, освіти, економіки та політики, а також їх рівноправної трудової інтеграції з викорененням ґендерної нерівності повинно реалізовуватися країнами на глобальному рівні, що посприяє побудові ефективної світової економіки та міжнародного суспільного ладу.

Дані Всесвітнього економічного форуму щодо рейтингу «Global Gender Gap Index, 2020» (індекс гендерного розриву) свідчать про те, що такі країни Північної Свропи, як Ісландія, Норвегія і Фінляндія $є$ країнами-лідерами за гендерною рівністю між чоловіками та жінками (рис. 1). Останні три місця в рейтингу займають Пакистан $(56,4$ \%), Ірак (53 \%) і Ємен (49,4 \%). Україна в цьому рейтингу займає 59-у позицію $(0,721$ балів) зі 153-х країн, поступаючись Гондурасу $(0,722)$ та випереджаючи Хорватію $(0,720)$ (Global Gender Gap Report, 2020, p. 9).

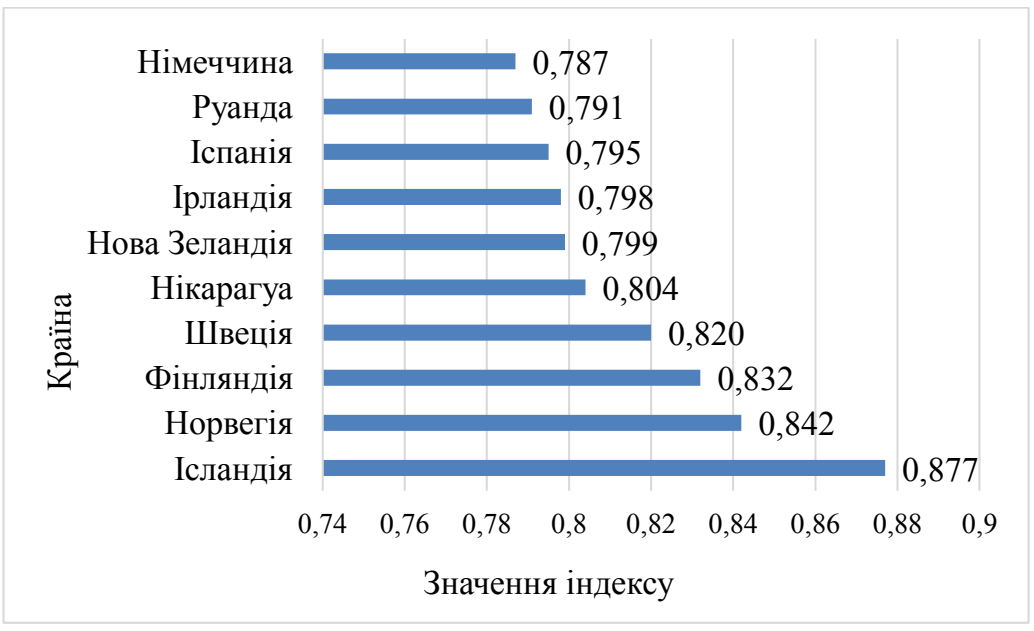

Рис. 1 Рейтинг країн-лідерів по індексу гендерного розриву у 2020 р.

При цьому у 2014 р. Україна займала 56те місце зі 142 досліджуваних країн за гендерною рівністю, включаючи 31 місце за економічною участю (на 2020 р. - 39 місце), 29 місце за рівнем освіти (на 2020 р. - 26 місце), 105 місце за політичним представництвом (на 2020 р. - 83 місце) та 74 місце в сфері здоров'я (на 2020 р. - 52 місце) (Global Gender Gap Report, 2014, p. 10-11; Global Gender Gap Report, 2020, p. 12-13]. У порівнянні з 2014 р. індекс гендерного розриву в Україні свідчить про збільшення гендерної нерівності в країні, що вкрай є неба- жаним чинником для процвітання економіки і побудови згуртованого суспільства.

На прикладі гендерного моніторингу позачергових парламентських виборів народних депутатів України у 2014 та 2019 рр., можна проаналізувати можливості та перешкоди для участі жінок у виборах та їх обрання до Верховної Ради України (далі - ВРУ). Незважаючи на гендерні квоти, які встановлені виборчим законодавством України (у 2013 p. була ухвалена законодавча квота - 30 \%), гендерний баланс серед обраних депутатів та серед учасників виборчого процесу на по- 
зачергових виборах народних депутатів ще у 2014 р. характеризувався меншістю участі жінок у виборчому процесі. За результатами позачергових парламентських виборів у 2014 р. тільки 12,5 \% жінок потрапили до парламенту - 3423 народних депутатів у ВРУ налічувалося всього 53 жінки-депутата. Проте можна відзначити, що цей показник збільшився в порівнянні з парламентськими виборами 2012 року, коли до парламенту пройшло трохи більше $9 \%$ жінок. У той же час у середньому в світі жінки займають 22 \% місць у національних парламентах, що говорить про незадовільний рівень гендерного балансу у ВРУ (Скільки жінок серед нардепів, міністрів, мерів та голів сільрад, 2018). Результати позачергових парламентських виборів у 2019 р. показали позитивну тенденцію збільшення рівня представництва жінок у ВРУ (20,28 \%), що є по суті найвищим показником з 1991 р. Однак у загальному гендерному представництві рівень участі жінок на позачергових парламентських виборах у 2019 р. та у 2014 р. залишається гендерно незадовільним - значно поступається чоловікам-депутатам (рис. 2).

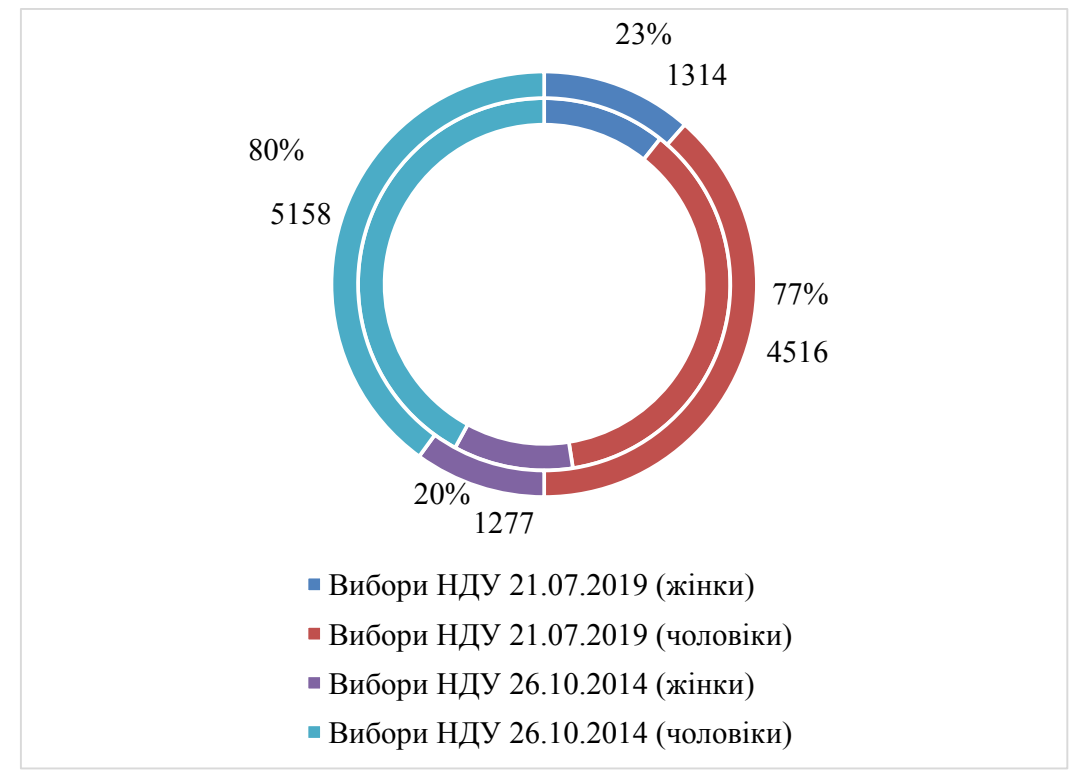

Puc. 2 Гендерне представництво кандидатів на позачергових виборах народних депутатів України у 2014 та 2019 pp.

Гендерний моніторинг місцевих виборів у 2015 р., проте, показав, що у місцевих виборах представниці жіночої статті мали більше можливостей потрапити до органів влади. Це пов'язано передусім з меншою значущістю депутатського мандату в порівнянні з парламентським. У 144 містах обласного значення та у так званих містах-супутниках мерами стали тільки 8 жінок, у містах районного значення -14 жінок зі 146 мерів. Проте, зі 394 голів селищних рад на виборах перемогли 76 жінок (19,3\%), а сільські ради очолили 2256 жінок (32,1 \%) з 7029 сільрад. Можна побачити, що тільки на рівні сільрад жінки-депутати подолали 30-відсоткову виборчу квоту, яка за32 лежить, у свою чергу, від взаємозв'язку між рівнем органу влади і кількістю жінок в ньому (Скільки жінок серед нардепів, міністрів, мерів та голів сільрад, 2018).

Рівень представництва жінок на позачергових парламентських виборах у 2019 p. у загальнодержавному багатомандатному виборчому окрузі досяг рівня передбачених гендерних квот. Рівень представництва жінок-кандидатів у загальнодержавному багатомандатному склав 30,3 7\%, а за виборчими списками від політичних партій, які подолали $5 \%$ виборчий бар'єр, з 225 депутатів до Верховної Ради України пройшли 59 жінок. (рис. 3). Що стосується одномандатних ви- 
борчих округів, то, у порівнянні з часткою чоловіків-кандидатів в одномандатні виборчі округи, частка жінок-кандидаток залишається вкрай низькою, що можна побачити на рис. 3. Зі 199 депутатів до ВРУ пройшли 27 (14 \%) жінок - 25 від політичних партій та 2 жінки-самовисуванки. Тому участь у виборах за мажоритарною виборчою системою в одномандатних виборчих округах була менш сприятливою для жінок-кандидаток, у порівнянні з участю за виборчими списками (Жінки на виборах: біг з перешкодами).

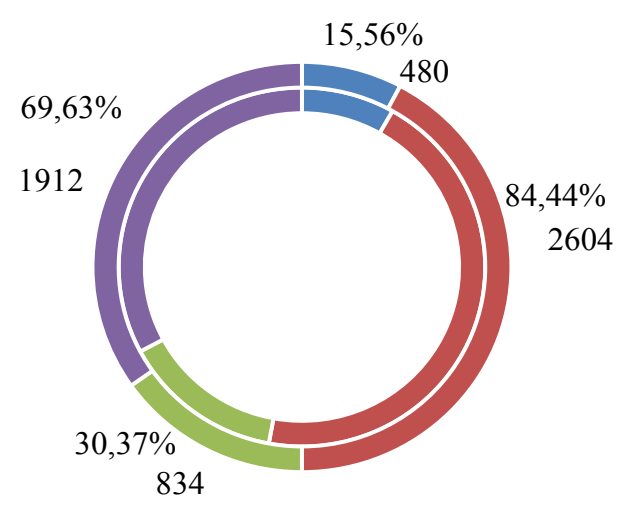

$$
\begin{aligned}
& \text { - Одномандатні виборчі округи (жінки) } \\
& \text { - Одномандатні виборчі округи (чоловіки) } \\
& \text { - Загальнодержавний багатомандатний виборчий округ (жінки) } \\
& \text { - Загальнодержавний багатомандатний виборчий округ (чоловіки) }
\end{aligned}
$$

Рис. 3 Гендерне представництво кандидатів у загальнодержавному багатомандатному та одномандатних виборчих округах на виборах народних депутатів України в 2019 р.

Найбільш позитивну тенденцію показало представництво жінок у складі окружних виборчих комісій з виборів народних депутатів України у 2019 р. (рис. 4). До того ж зі 199 окружних виборчих комісій 59 \% жінок перебували в їх складі. Част- ка жінок на керівних посадах в окружних виборчих комісій становила $58 \%$, серед голів окружних виборчих комісій $-49 \%$, серед заступників голів - 56 \% та серед секретарів - 69 \% (Жінки на виборах: біг 3 перешкодами).

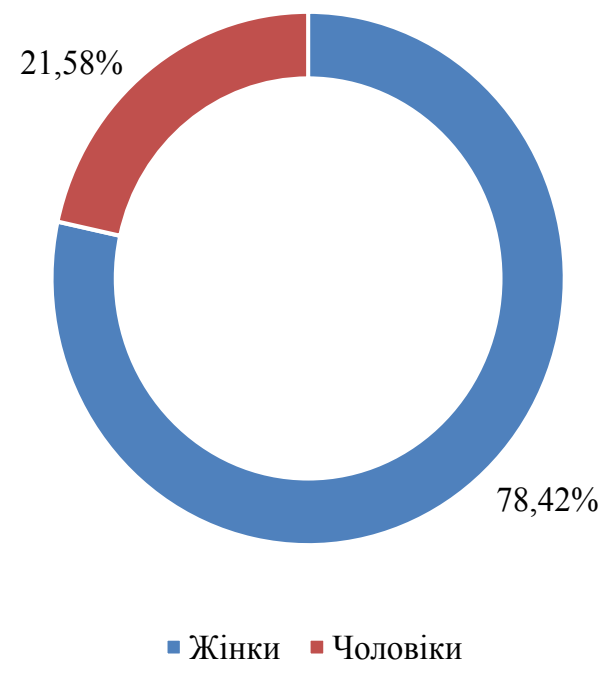

Рис. 4 Гендерне представництво у складі дільничних виборчих комісій 
Таким чином, можна відзначити, що наразі гендерна дискримінація жінок в політичній та економічній сфері діяльності в Україні зазнає змін у позитивний бік. Поступове збільшення можливостей жінок займати високі посади на державній службі, розширення їх прав щодо професійної орієнтації, зокрема, за рахунок скасування наказу Міністерства охорони здоров’я № 256 «Про затвердження Переліку важких робіт і робіт зі шкідливими і небезпечними умовами праці, на яких забороняється застосування праці жінок» у 2017 р., є повільними, але впевненими кроками дій держави на шляху до подолання гендерної дискримінації жінок. Слід окремо зазначити, що викорінення професійної нерівності жінок щодо чоловіків, $\epsilon$ важливим чинником для наближення національного законодавства до вимог законодавства $€ C$, міжнародних зобов'язань України 3 питань гендерної політики та економічного зростання країни. Як свідчить досвід різних країн світу, гендерна нерівність участі жінок в економічній та політичній сфері, призводить до гальмування реалізації потенціалу людського капіталу та втрат національного багатства країн. Найбільші втрати спостерігаються у розвинених країнах-учасниць ОЕСР Свропи та Центральної Азії (30,8 \%) приблизно 140,2 трлн грн, у решті країн - 20 трлн грн. Залежно від відсотка втрат людського капіталу щодо сукупного обсягу багатства, найбільших втрат сукупного багатства зазнали країни з доходом нижче середнього (близько 19,4 \%), а найменше - країни з високими доходами, які не є членами ОЕСР (близько 7,4 \%). Саме ліквідація гендерної нерівності за доходами збільшить обсяги людського капіталу в світовій економіці на $21,7 \%$, а світове багатство - на $14 \%$. Тому Україна як держава, яка прагне до економічного зростання та найбільш повного використання всього iï трудового потенціалу, мусить продовжувати розширювати економічні можливості жінок, забезпечувати їх рівні можливості представництва та участі 34 у політичному та суспільному житті, захищати на законодавчому рівні жінок від гендерно зумовленого насильства та всіх форм дискримінації.

\section{Висновки.}

Отже, можна побачити, що за останні декілька років Україна досягла значного прогресу щодо ухвалення та вдосконалення базових нормативно-правових документів у сфері ґендерної рівності, що є нагальною потребою для посилення соціальної політики гендерного рівноправ'я в державі. Слід звернути увагу на те, що Україна стала єдиною державою, яка прийняла Національний план дій з виконання рекомендацій, викладених у заключних зауваженнях Комітету ООН з ліквідації дискримінації щодо жінок, перебуваючи у військовому конфлікті. Поступове розширення політичних повноважень жінок та дотримання гендерного паритету на вищих посадах державного управління, а також згладжування професійної сегрегації за ознакою статі, як показали дані Всесвітнього економічного форуму в рейтингу Global Gender Gap Index (2020), починають відповідати вимогам представницької демократії та просування подальших гендерних перетворень в інших сферах життя суспільства України.

Проте постає проблема подальшого вдосконалення ефективних механізмів дотримання правових норм Конституції України та інших законів, основних міжнародних договорів 3 питань гендерної рівності та прав жінок, які гарантують рівність чоловіків та жінок у всіх сферах життя. Тому для ефективної боротьби 3 гендерною сегрегацією, насильством в суспільстві та 3 сексизмом в часи збройного конфлікту та формування постконфліктного суспільства, необхідно спрямувати зусилля держави на зміцнення інституційного механізму щодо забезпечення гендерної рівності та комплексного підходу до ліквідації організаційних бар'єрів для державного реагування на гендерну нерівність (Цілі Сталого Розвитку: Україна: 
Національна доповідь, 2017, с. 44). Оцінюючи сучасний прогрес України в сфері подолання гендерної дискримінації жінок, зокрема, у процесі розвитку політичної і правової концепції побудови держави, основними завданнями в соціальній політиці країни щодо усунення гендерної асиметрії повинні стати:

1. Посилення дієвості антидискримінаційного законодавства України стосовно ліквідації всіх форм дискримінації щодо жінок і зміцнення державних структур на національному та місцевому рівнях, що забезпечують гендерну рівність.

2. Інтеграція гендерного питання в державну політику (у стратегічне планування та національні пріоритети всіх реформ) 3 кращою доступністю до детальних даних гендерної статистики.

3. Створення сприятливих умов на законодавчому рівні для поєднання професійних і сімейних обов'язків жінок $з$ дітьми, а саме: розширення можливостей дистанційної зайнятості та застосування гнучкого робочого часу, запровадження обов'язкових батьківсь- ких відпусток при народженні дитини, розвиток мережі дошкільних дитячих закладів, особливо в сільській місцевості (Цілі Сталого Розвитку: Україна: Національна доповідь, 2017 , с. 44). Окрім цього, необхідно забезпечити можливості професійної реалізації жінок у межах конкурсів СС для молоді та подолати гендерний розрив жінок у доступі до фінансів та інше.

Прийняття й удосконалення державних стратегій 3 вищезазначеними завданнями сприятиме просуванню гендерної рівності в Україні та розширенню прав і можливостей жінок. Покращення доступу жінок до медичних, освітніх, правових та соціальних послуг, розширення економічних можливостей жінок, удосконалення механізмів ефективності розслідування випадків гендерного насильства над жінками та своєчасної допомоги постраждалим особам тощо, є необхідними чинниками формування ефективного суспільного ладу в Україні та просування євроінтеграційного курсу держави на новий рівень 3 найбільш конкурентоспроможним людським капіталом.

\section{БІБЛІОГРАФІЧНІ ПОСИЛАННЯ}

Азбука прав працюючих жінок і гендерної рівності. 2-ге вид. Женева : Міжнародне бюро праці, 2010. 244 с.

Архіпов В. І. Проблеми дотримання прав людини в умовах трансформаційних процесів сучасної України. Політологічні записки. Вип. 3. Луганськ : Вид-во СНУ ім. В. Даля, 2011. С. 97-102.

Гербут Н. А. Вплив виборчих систем на гендерне представництво у Верховній Раді України. Наукові записки Iнституту політичних і етнонаціональних досліджень ім. I. Ф. Кураса НАН України. 2015. Вип. 2. С. $266-280$.

Гербут Н. А. Формування егалітарного світогляду у політичному вимірі: концептуально-історичний аналіз. Наукові записки Інституту політичних і етнонаціональних досліджень ім. I. Ф. Кураса. 2013. Вип. 1. С. 337-352.

Гендерна рівність. Відновлено з: http://www.un.org.ua/ua/nasha-robota/gender.

Державна служба статистики України. Відновлено 3: http://www.ukrstat.gov.ua.

Дідух Г. Я. Формування іміджу жінки-політичного лідера : автореферат дис. ... канд. політ. наук : 23.00.02 / Нац. пед. ун-т ім. М. П. Драгоманова. Київ, 2010. 20 с.

Жінки на виборах: біг з перешкодами. Відновлено з: https://www.uwf.org.ua/news/11582.

Про забезпечення рівних прав та можливостей жінок і чоловіків : Закон України № 2866-IV. Офічійний вісник України. 2005. № 40. С. 48.

Конституція України. Відновлено з: https://zakon.rada.gov.ua/laws/main/254к/96-вр.

Літвін Л. А. Забезпечення гендерної рівності як чинник демократизації політичних інститутів України : автореф. дис. ... канд. політ. наук : 23.00.02. Луганськ, 2012. 20 с.

Марценюк Т. О. Жінки в українській політиці: виклики і перспективи змін. Київ : Міжнародний центр перспективних досліджень, 2015. 35 с.

Мельник Т. М. Творення суспільства гендерної рівності: міжнародний досвід. Закони зарубіжних країн з гендерної рівності. Київ : Стилос, 2010. 440 с

Оцінка потреб та можливостей зайнятості внутрішньо переміщених осіб в Україні: узагальнення результатів дослідження та рекомендації / Міжнародна організація праці. Будапешт, 2016. Відновлено 3: http://ilo.org/budapest/whatwe-do/publications/WCMS 464289/lang--en/index.htm.

Скільки жінок серед нардепів, міністрів, мерів та голів сільрад. Відновлено 3: https://www.slovoidilo.ua/2018/03/08/ infografika/polityka/skilky-zhinok-sered-nardepiv-ministriv-meriv-ta-holiv-silrad. 
Сприяння рівності. Гендерно нейтральне оцінювання робіт щодо рівної оплати : поетапний посіб. Женева : Міжнар. бюро праці, 2009. 104 с.

Цілі Сталого Розвитку: Україна: Національна доповідь. 2017. Міністерство економічного розвитку і торгівлі України. Коорд. Н. Горшкова. 176 с. Відновлено з: https://prod-ecology-portal.kitsoft.kiev.ua/17\%20ukr.pdf.

Черба В. М., Ромашко І. Ю. Гендерна нерівність на ринку праці України. Ефективна економіка. 2016. № 5. Відновлено 3: http://nbuv.gov.ua/UJRN/efek_2016_5_40.

Кэрролл С., Зерилли Л. М. Дж. Феминиистские вызовы политической науке. Общественные науки и современность. 2001. № 6. С. 61-83.

Марценюк Т. Гендерные квоты в Украине: быть или не быть? Информационно-просветительское издание «Я». 2007. № 1 (17). С. 18-22.

Рейтинг стран мира по уровню экономической свободы. Гуманитарная энциклопедия: Исследования. Центр гуманитарных технологий, 2006-2020 (последняя редакиия: 08.02.2020). Відновлено з: https:/gtmarket.ru/ratings/index-ofeconomic-freedom/index-of-economic-freedom-info.

Global Gender Gap Report 2014. Відновлено 3: http://www3.weforum.org/docs/GGGR14/GGGR_CompleteReport_2014.pdf.

Global Gender Gap Report 2020. Відновлено 3: http://www3.weforum.org/docs/WEF_GGGR_ 2020.pdf.

\section{REFERENCES}

Azbuka prav pratsiuiuchykh zhinok i hendernoi rivnosti [ABC of women workers' rights and gender equality]. (2010). 2nd ed. (No. 2, p. 244). Zheneva: Mizhnarodne biuro pratsi 2, 244 [in Ukrainian].

Arkhipov, V. I. (2011). Problemy dotrymannia prav liudyny v umovakh transformatsiinykh protsesiv suchasnoi Ukrainy [The problem of respect for human rights in the context of the transformation of the processes of modern Ukraine]. Politolohichni zapysky - Political science notes, 3, 97-102 [in Ukrainian].

Gerbut, N. A. (2015). Vplyv vyborchykh system na henderne predstavnytstvo u Verkhovnii Radi Ukrainy [The Impact of electoral systems on gender representation in the Verkhovna Rada of Ukraine]. Naukovi zapysky Instytutu politychnykh i etnonatsionalnykh doslidzhen im. I. F. Kurasa NAN Ukrainy - Scientific Notes of Kuras Institute of Political and Ethnic Studies of NAS of Ukraine, 2, 266-280 [in Ukrainian].

Gerbut, N. A. (2013). Formuvannia ehalitarnoho svitohliadu u politychnomu vymiri: kontseptualno-istorychnyi analiz [Formation of egalitarian gender attitudes in the political dimension: conceptual and historical analysis]. Naukovi zapysky Instytutu politychnykh i etnonatsionalnykh doslidzhen im. I. F. Kurasa-Scientific notes of the I. F. Kuras Institute of politic and ethnic studies, 1, 337-352 [in Ukrainian].

Genderna rivnist [Gender inequality]. Retrieved $\neg$ from $\neg$ http://www.un.org.ua/ua/nasha-robota/gender [in Ukrainian].

Derzhavna sluzhba statystyky Ukrainy [State Statistics Service of Ukraine]. Retrieved from http://www.ukrstat.gov.ua.

[in Ukrainian].

Didukh, H. J. (2010). Formuvannia imidzhu zhinky-politychnoho lidera [Image-making of Female Political Leader].

Extended abstract of candidate's thesis. National Pedagogical Dragomanov University [in Ukrainian].

Zhinky na vyborakh: bih z pereshkodamy [Women in Elections: Hurdle Race]. Retrieved from https://www.uwf.org.ua/ news/11582 [in Ukrainian].

On ensuring equal rights and opportunities of women and men. No.2866-IV. (2005) Ofitsiinyi visnyk Ukrainy - Official bulletin of Ukraine, 40, art. 48 [in Ukrainian].

Konstytutsiia Ukrainy [Constitution of Ukraine]. Retrieved $\neg$ from https://zakon.rada.gov.ua/laws/main/254к/96-вр [in Ukrainian].

Litvin L. A. (2012). Zabezpechennia hendernoi rivnosti yak chynnyk demokratyzatsii politychnykh instytutiv Ukrainy [Ensuring gender equality as a factor in the democratization of Ukraine 's political institutions]. Extended abstract of candidate's thesis [in Ukrainian].

Martsenyuk, T. O. (2015) Zhinky v ukrainskii politytsi: vyklyky i perspektyvy zmin [Women in Ukrainian Politics: Challenges and Prospects for Change]. Mizhnarodnyi tsentr perspektyvnykh doslidzhen-International Centre for Advanced Studies, 35 [in Ukrainian].

Melnyk T. M. (2010). Tvorennia suspilstva gendernoi rivnosti: mizhnarodnyi dosvid. Zakony zarubizhnykh krain z gendernoi rivnosti [Building a gender equality society: international experience. Foreign laws on gender equality]. Stylos Stylos, 440 [in Ukrainian].

Otsinka potreb ta mozhlyvostei zainiatosti vnutrishno peremishchenykh osib v Ukraini: uzahalnennia rezultativ doslidzhennia ta rekomendatsii [Employment needs assessment and employability of internally displaced persons in Ukraine: summary of survey findings and recommendations]. (2016). Mizhnarodna orhanizatsiia pratsi. Retrieved from http://ilo.org/budapest/what-we-do/publications/WCMS_464289/lang--en/index.htm [in Ukrainian].

Skilky zhinok sered nardepiv, ministriv, meriv ta holiv silrad [How many women are among the people's deputies, ministers, mayors and village council heads]. Retrieved from https://www.slovoidilo.ua/2018/03/08/infografika/polityka/ skilky-zhinok-sered-nardepiv-ministriv-meriv-ta-holiv-silrad [in Ukrainian].

Spryiannia rivnosti. Genderno neitralne otsiniuvannia robit shchodo rivnoi oplaty : poetapnyi posib. [Gender-neutral job evaluation for equal pay. A step-by-step guide]. (2009). Zheneva: Mizhnar. biuro pratsi [in Ukrainian].

Tsili Staloho Rozvytku: Ukraina: Natsionalna dopovid [Sustainable Development Goals in Ukraine]. (2017). Ministerstvo ekonomichnoho rozvytku i torhivli Ukrainy [in Ukrainian].

Cherba, V. M. (2016). Henderna nerivnist na rynku pratsi Ukrainy [Gender inequality on the labor market in Ukraine]. Efektyvna ekonomika - Effective economy, 5. Retrieved from http://nbuv.gov.ua/UJRN/efek_2016_5_40 [in Ukrainian].

Carroll, S. J., \& Zerilli, L. M. (2001) Feministskie vyizovyi politicheskoy nauke [Feminist Challenges to Political Science]. Obschestvennyie nauki i sovremennost - Social sciences and modernity, 6, 61-83 [in Russian]. 
Martsenyuk, T. (2007) Gendernyie kvotyi v Ukraine: byit ili ne byit? [Gender quotas in Ukraine: be or not be?]. Informatsionno-prosvetitelskoe izdanie «Ya»-Information and educational edition «Ya», 1 (17), 18-22 [in Russian].

Reyting stran mira po urovnyu ekonomicheskoy svobodyi. Gumanitarnaya entsiklopediya: Issledovaniya [Rating of the countries of the world by the level of economic freedom. Humanitarian encyclopedia: Researches]. (2020). Tsentr gumanitarnyih tehnologiy - Center of humanitarian technologies. Retrieved from https:/gtmarket.ru/ratings/index-ofeconomic-freedom/index-of-economic-freedom-info.

Global Gender Gap Report 2014. Retrieved from: http:/www3.weforum.org/docs/GGGR14/GGGR_ CompleteReport 2014.pdf.

Global Gender Gap Report 2020. Retrieved from: http://www3.weforum.org/docs/WEF_GGGR_2020.pdf.

\section{Костюк Наталя}

Кандидат філософських наук, доцент Дніпровський національний університет залізничного транспорту ім. академіка В. Лазаряна

Email: senya4216@gmail.com

\author{
Антонюк Олена \\ Кандидат юридичних наук, доцент \\ Дніпровський національний університет \\ залізничного транспорту ім. академіка В. Лазаряна \\ Email: senya4216@gmail.com
}

\section{Kostiuk Natalia}

Ph.D. of Philosophy Sciences, Assoc. Prof.

Dnipro National University of Railway Transport named after Academician V. Lazaryan

\author{
Antoniuk Olena \\ Ph.D. of Juridical Sciences, Assoc. Prof. \\ Dnipro National University of Railway Transport \\ named after Academician V. Lazaryan
}

Цитування: Костюк, Н., \& Антонюк, О. (2020). Гендерна рівність. Аспекти публічного управління, 8 (3), 25-37. doi: 10.15421/152067

Citation: Kostiuk, N., \& Antoniuk, O. (2020). Genderna rivnist [Gender inequality]. Public administration aspects, 8 (3), 25-37. doi: 10.15421/152067

Стаття надійшла / Article arrived: 07.07.2020

Схвалено до друку / Accepted: 18.08.2020 